RESEARCH PAPER

\title{
Thinking the "unthinkable": why Philip Morris considered quitting
}

\section{E A Smith, R E Malone}

Tobacco Control 2003;12:208-213

See end of article for authors' affiliations

\section{Correspondence to}

Elizabeth A Smith, PhD,

Department of Social and Behavioral Sciences, Box 0612, Laurel Heights Campus, University of California, San Francisco, San Francisco, California, 94143, USA

libbys@itsa.ucsf.edu

Received 6 August 2002. Accepted 22 January 2003

\begin{abstract}
Objective: To investigate the genesis and development of tobacco company Philip Morris's recent image enhancement strategies and analyse their significance.

Data sources: Internal Philip Morris documents, made available by the terms of the Master Settlement Agreement between the tobacco companies and the attorneys general of 46 states, and secondary newspaper sources.

Study selection: Searches of the Philip Morris documents website (www.pmdocs.com) beginning with terms such as "image management" and "identity" and expanding as relevant new terms (consultant names, project names, and dates), were identified, using a "snowball" sampling strategy.

Findings and conclusions: In the early 1990s, Philip Morris, faced with increasing pressures generated both externally, from the non-smokers' rights and public health communities, and internally, from the conflicts among its varied operating companies, seriously considered leaving the tobacco business. Discussions of this option, which occurred at the highest levels of management, focused on the changing social climate regarding tobacco and smoking that the tobacco control movement had effected. However, this option was rejected in favour of the image enhancement strategy that culminated with the recent "Altria" name change. This analysis suggests that advocacy efforts have the potential to significantly denormalise tobacco as a corporate enterprise.
\end{abstract}

D efining the tobacco industry as "the vector of the tobacco epidemic"1 has been a powerful strategy for tobacco control advocates, beginning in the late 1980s. Such industry focused strategies have included efforts to "denormalise" the tobacco business by exposing companies' illegal or unethical practices ${ }^{2-5}$ and encouraging their isolation through boycotts, institutional rejection of industry funding, ${ }^{6}$ and divestment. ${ }^{7}$ These strategies have brought new energy to tobacco control efforts, proved an effective approach to reducing smoking rates, ${ }^{89}$ and put the industry on the defensive.

For the past 12 years, Philip Morris has been engaged in a comprehensive image enhancement strategy, at least in part in response to industry focused tobacco control efforts. This study of Philip Morris documents shows that these pressures prompted serious consideration at Philip Morris's top executive levels of extricating the company from tobacco altogether. Ultimately, however, the company proved unable or unwilling to end its tobacco addiction, and instead continues to remake its public image, with, for example, its recent change of the company's name to "The Altria Group". ${ }^{10} 11$

\section{METHODS}

Data were collected from the Philip Morris Incorporated document website (http://www.pmdocs.com/), which provides access to millions of company documents released as a result of state attorneys general lawsuits and other cases. Between 15 January 2002 and 9 July 2002, we searched the Philip Morris website for documents related to the company's identity and reactions to public pressure. We used a variety of search terms including "image management" and "identity". Searches were extended using names of individuals and consulting companies, dates, and other indexing information in a "snowball" search strategy. Further information on document collections and searching strategies is provided in earlier work. ${ }^{12}$ To facilitate ongoing access, we have replaced the Philip Morris website URLs in our citations with URLs of the same documents available on the Legacy Tobacco Documents
Library website, which will remain accessible to the public after the industry sites are closed. We reviewed more than 400 company documents, Lexis/Nexis searches of more than 50 major newspapers, and relevant Securities and Exchange Commission filings. We analysed the documents using a chronological case study approach.

\section{FINDINGS}

Corporate image became a major concern for Philip Morris in the late 1980s. This concern derived from executives' perception-confirmed by extensive research-that the company had a poor reputation with the public and with legislators and other opinion leaders. In company ordered opinion polls, Philip Morris was consistently rated less favourably than other major companies, ${ }^{13-15}$ including Exxon, ${ }^{16}$ despite the highly publicised 1989 Exxon Valdez oil spill. A 1990 Roper study concluded that Philip Morris experienced a "decline in popularity" between 1980 and 1990, even though "large corporations in general" were rated more positively at the end of the decade. ${ }^{17}$ Philip Morris even fared poorly compared to RJR Nabisco (RJR), its closest tobacco competitor. ${ }^{18}$ Philip Morris's pollsters, the Wirthlin Group, attributed RJR's relative popularity to its success "in obscuring its tobacco company association". ${ }^{19}$

Even without this research, Philip Morris executives were cognisant of their image problem. Consultants and executives used startling language to describe themselves and their business. At a 1991 meeting, image consultants likened the business to prostitution, alcoholism, and drug trafficking. They suggested that Philip Morris's position was similar to "VW after WWII" - that is, a company known for doing business with Nazis. ${ }^{20}$ "Who were the bad boys over this past centurywhat happened to them?" one of the consultants asked, evidently looking for a model. ${ }^{20}$ At one meeting executives were asked to consider the actions of the asbestos industry in their brainstorming. ${ }^{21}$ A team organised to work on the "declining media climate" unanimously agreed that the "situation is rapidly deteriorating". ${ }^{22}$ The health hazards of tobacco 


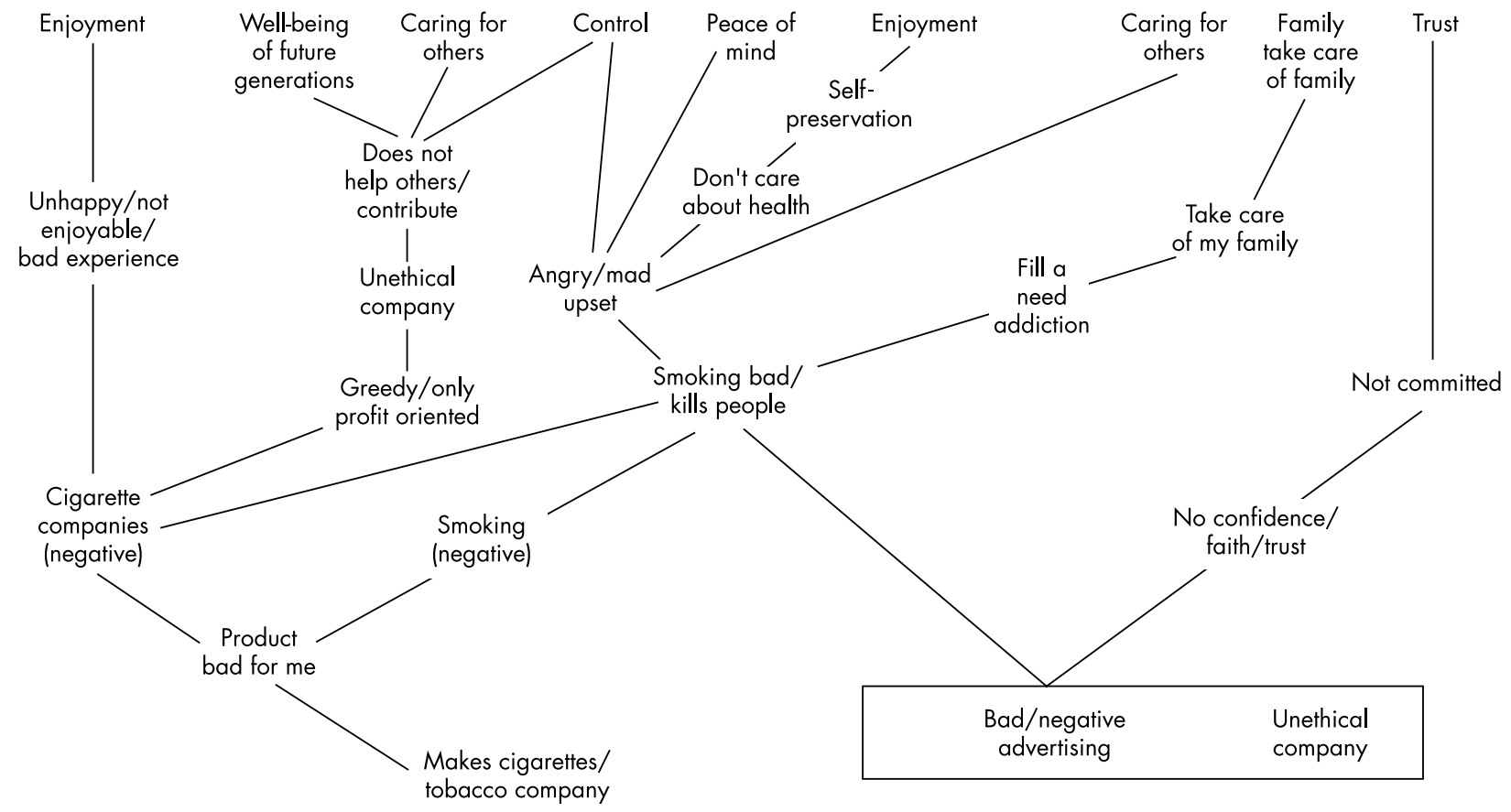

Figure 1 Negative perceptual orientations toward Philip Morris: among all respondents. Adopted from Philip Morris Wirthlin Group. Philip Morris companies a national opinion survey-topline results. January 1993. URL: http://legacy.library.ucsf.edu/tid/lav42e00.

use were central to the problem (fig 1). ${ }^{23}$ A few years later, a Corporate Communications Taskforce summarised media perception of the company as "evil ... selling a lethal product". ${ }^{24}$

That perception was causing some institutional investorsnotably Harvard, Johns Hopkins, and the City University of New York-to divest their portfolios of tobacco stock. ${ }^{25} 26$ Divestment may have been particularly alarming because a survey of stock analysts declared Philip Morris to be "primarily a stock for professional or institutional investors." Whereas individuals make investment decisions based in part on "emotion," and thus might be reluctant to buy tobacco stock, institutions "only care about making money". ${ }^{27}$ If institutions were divesting, there was cause for concern. Image also affected stock price directly. Philip Morris's public relations firm told the company that "as [the] 'tobacco' image of Philip Morris increases, [the] market value of Philip Morris decreases". ${ }^{28}$ Analysts told Philip Morris that "their clients discount the price they'll pay for Philip Morris by about 40 percent because of the 'litigation time bomb" - the fear that Philip Morris's winning streak in the courts would end. ${ }^{27}$

Employee morale was a related problem. Philip Morris executives made repeated references to this concern from the early 1990s on. In 1990, RW Murray, vice chairman of Philip Morris Corporation, worried that "severe morale problems" could arise "in the next few years". ${ }^{21}$ By 1993, such problems were noticeable to outside board members, who remarked that they were "expected when a company is going down, but PM USA is still wildly profitable" ${ }^{29}{ }^{30}$ A year later, Murray said that morale was his "one significant concern about our future tobacco business". ${ }^{31}$ Philip Morris's acquisition of Kraft in 1988 may have exacerbated these problems, since food employees were not necessarily eager to work for a tobacco company. After the Kraft merger one employee asked whether "we really want our food customers to know that we are owned by a cigarette company?" Murray responded that none of the operating companies "need be ashamed to be associated with" the others. ${ }^{32}$

Company image problems derived from several sources, including litigation threats, increased regulatory efforts on the federal, state, and local levels, and a shrinking domestic market for tobacco. Philip Morris management attributed these factors to the increased effectiveness of the tobacco control movement. As early as 1987, minutes from a brainstorming session on environmental tobacco smoke declared that in the USA the tobacco "industry is going down" and tobacco control forces were characterised as a "REAL ADVERSARY" (emphasis in original). ${ }^{33}$ In 1990, Murray commented that the "large number of anti-smoking activists in America" were "effective and becoming more so" ${ }^{34}$ John Dollisson, the vice president of corporate affairs at Philip Morris International, warned Infotab, the industry's international intelligence and research organisation, that it was time to "wake up to the fact that we are loosing [sic] the battle" and that many of "the enemy .. really are a lot smarter than we are" (emphasis in original)..$^{35}$ The business climate, another executive agreed, was "terrible" as a result of " 25 years of criticisms" and the "rise of public health advocacy groups" ${ }^{21}$ Senior vice president Marc Goldberg declared: "Anti-tobacco sentiment has infected a wide range of our business operations and performance." ${ }^{\prime 36}$ This "sea change" in the business climate, as CEO Michael A Miles characterised it, ${ }^{37}$ called for strong measures.

\section{STRATEGIES \\ Dump tobacco}

The most extreme possibilities Philip Morris considered were getting out of or "skimming off" the tobacco business. In 1987, before the Kraft acquisition, some executives suggested that Philip Morris should assume it was playing an "end game" and "maximize cash flow" - that is, focus exclusively on short term profits. Such a "controlled retreat" would probably accelerate "into an abrupt end" they thought, so "fighting back" was preferable. ${ }^{33}$ By 1990, when a larger proportion of profits came from food products, this conclusion was no longer a given. In that year, vice chairman Murray wrote that "tobacco is a [sic] could be a dying industry". He continued: "I think we all believe that our future lies outside tobacco, and principally in the food business. I certainly believe this." ${ }^{\prime 34}$ The liabilities of tobacco were heavy and would probably get worse. Murray outlined two options: selling the tobacco business, or improving the business environment. Ultimately, Murray recommended that the latter be tried, but "If at the end of two years 
it looks like it is not working we should . . get rid of the tobacco business". ${ }^{34} \mathrm{~A}$ few months later Murray wrote that the company should "have [a] spin-off plan on [the] shelf ready to $\mathrm{go}^{\prime \prime} .^{38}$

In 1993, a year after Murray's deadline, board of directors member William Donaldson suggested that they "consider the 'unthinkable'-look at the skim off idea" ${ }^{39}$ In 1994 a formal proposal was made to the board, with the support of senior management, ${ }^{31}$ to separate the food and tobacco businesses. The idea was to "spin off" the food companies (Kraft General Foods, both domestic and international), giving shareholders in Philip Morris equivalent shares in the new entity. Another, similar plan, separated domestic tobacco from food, beer, and international tobacco interests. The objectives were to "monetize ... Domestic Tobacco's ("DT") ...value" and "separate DT from [Philip Morris] thereby clarifying [Philip Morris's] valuation". ${ }^{40}$

The problem with Philip Morris's valuation was that food companies tended to have higher price/earnings (PE) multiples than tobacco companies, and, as far as the market was concerned, Philip Morris traded "like a domestic tobacco company-not like a food company" ${ }^{41}$ Thus when Philip Morris acquired new food operations, they paid "food industry multiples ... which are subsequently valued at the company's lower ...multiple" ${ }^{36}$ In other words, because Philip Morris was a tobacco company, its purchases immediately lost value because of the association. This made "acquisitions difficult to justify financially". ${ }^{36}$

In similar circumstances, RJR Nabisco had made a less extreme proposal in 1993. The company had proposed to issue "targeted stock" that would follow its food businesses. In RJR Nabisco's case, however, the division would have been only on paper, with the company remaining intact, sharing assets and liabilities. Stockholders in the food company would not have been protected from losses in court by the tobacco side. ${ }^{42}$ RJR Nabisco's proposal was withdrawn because of "tepid" demand for the new stock. ${ }^{43}$

The most detailed description of Philip Morris's spin-off plan, a speech delivered by Marc Goldberg to the board, argued that it would improve the fortunes of both food and tobacco. The food company's PE multiple would go up, its employees' morale would improve (in part because of the increased value of their stock holdings), and it would no longer be vulnerable to actions such as the INFACT boycott of Kraft products (www.infact.org). On the tobacco side, Goldberg said, the company would be able to respond to actions against it without worrying about the impact on food (for example, fighting McDonald's decision to go smoke-free without damaging its relationship with Kraft) and "to pursue different financial strategies for each part of the business". ${ }^{36}$

There were some hints that this strategy might not be quite as effective for the tobacco business as Goldberg implied. Goldberg claimed that "new tobacco investors would more likely be sophisticated about the stock market realities of investing in a tobacco stock" and would therefore react less precipitously to bad news. However, he also asserted that employees' "incentive compensation would be more cash based than stock based". ${ }^{36}$ This suggests that he did not believe that the stock value on the tobacco side would improve as it was expected to do for food. Indeed, one stock analyst asked whether "anyone on earth would invest in a pure tobacco firm". ${ }^{40}$

Nonetheless, Philip Morris's spin-off plan had the support of "all members of senior management", ${ }^{11}$ including Philip Morris CEO Miles. ${ }^{44}$ (Miles, the only non-tobacco man ever to head Philip Morris, had previously been the CEO of Kraft.) Miles attributed his support of this strategy to "the environmental problems facing our US tobacco business", specifically "negative media coverage", "the barrage of litigation", and INFACT's initiation of "the first serious organized boycott effort directed against our non tobacco products" ${ }^{44}$
Philip Morris floated the spin-off idea to the business community in April $1994 .{ }^{45}$ The announcement that the company was considering such a move caused its stock to rise in the ensuing weeks. ${ }^{46}{ }^{47}$ Business reporters agreed with company management's assessment of the situation: the tobacco business, particularly because of "a growing wave of anti-smoking sentiment", ${ }^{48}$ was devaluing the food business. ${ }^{46} 4950$

The spin-off proposal was recommended for consideration to the board in April 1994, but withdrawn a month later on the advice of attorneys at Shook Hardy \& Bacon and Arnold \& Porter. ${ }^{37}$ Shortly after that, Miles stepped down, replaced by Murray and Geoffrey Bible, both long term tobacco executives. It does not appear that getting rid of tobacco was ever seriously raised again.

\section{IMAGE}

Even as they were considering the spin-off, the company was developing other options. These ranged from "ferocious defense" (organising politically and approaching the media more aggressively) $)^{51-53}$ to "Project Rainbow" (making strategic concessions to Congress in exchange for a period of "peace" ). ${ }^{54-58}$ Along with these strategies, company management emphasised image enhancement, a project in the works since 1989, culminating in the "Altria" name change. The Kraft takeover meant that a third of Philip Morris's income would come from food..$^{59}$ That shift in the balance, along with the acquisition of Kraft management's more aggressive style, ${ }^{60[008]}$ inspired a plan to "change the image of the company from that of a tobacco company to a large, agriculturally based consumer goods business" ${ }^{\prime 61}$ The public relations firm Burson Marsteller warned that such a change would take "courage and discipline". It would not occur if management violated the commandment "Thou shalt not BS thyself" by complaining that "media coverage is unfair" or simply asserting "we aren't a tobacco company". ${ }^{28}$ The project had two parts: company positioning and corporate name change.

\section{Positioning}

In 1993, the Wirthlin Group developed a set of possible "positioning concepts" for the company. The difficulty was finding a favourable position that bore a convincing relationship to the reality of Philip Morris. A good statement should "build on the positive impressions that ...stakeholder groups already hold". But Philip Morris's "perceived strengths", which included its size and contribution to the economy, were not as important to consumers as trustworthiness and caring about consumer health, attributes which it was very difficult for Philip Morris to claim. ${ }^{62}$ When concepts such as community commitment, good employee relations, and providing choice were attached to the Philip Morris name, surveys showed they all raised its image rating from the low 30 s to $55-63$ on a 100 point scale. But the consultants also pointed out that "ratings for a 'generic' company that meets any of the above descriptions is [sic] between 75-80". ${ }^{2}{ }^{63}$

Philip Morris's response was "PM21" or "Philip Morris in the $21^{\text {st }}$ Century." This project involved several components designed to improve the company image, including a "Youth Smoking Prevention" project, ${ }^{64-66}$ and refining and publicising the company's corporate giving programme. ${ }^{6768}$ The project also had an internal component, designed to make employees feel more positively about the company. ${ }^{69} 70$

\section{Name change}

The culmination of PM21 was the announcement in 2001 of the intention to change the company name to "The Altria Group". The primary reason for the name change was to "reduce the drag on the company's reputation that association with the world's most famous cigarette maker has caused". ${ }^{71}$ 
This paraphrase precisely conveys Philip Morris's hopes. Although it might be "associated with" tobacco, the company's primary identity would be something quite different. The company wanted to sever its image from tobacco without severing its financial ties. ${ }^{11}$

\section{DISCUSSION}

The tobacco control movement, which significantly changed public policies and public views on tobacco regulation during the late 1980s and early 1990s, was possibly even more effective than previously understood. This examination of internal Philip Morris documents shows how the company viewed its future prospects when tobacco control was in its ascendancy. Industry focused activism pushed the company to the "contemplation stage", inspiring high level corporate discussion about the future viability of the tobacco business. Specific concerns raised by Philip Morris included an increasingly negative media climate, boycott actions by groups such as INFACT, the drag of litigation risk on non-tobacco operating companies, conflicts between tobacco and non-tobacco companies under the Philip Morris corporate umbrella, declining employee morale because of the increasing social unacceptability of the industry, and public policy changes that reduced marketing opportunities and decreased tobacco use.

Had Philip Morris acceded to these pressures by selling its tobacco business, the immediate impact on tobacco sales and consumption would have been minimal. Another company, such as RJ Reynolds or British American Tobacco, would have been eager to acquire the business, particularly the leading brand, Marlboro. However, the long term impact could have been substantial in several ways.

Such a move by the dominant US tobacco company would have been a clear indication that, regardless of profits, continuing in such a business was socially untenable. The political power Philip Morris amassed would no longer have been focused on legitimising tobacco, perhaps creating an opportunity for tobacco control gains at the federal level. The increased consolidation of the tobacco business in companies engaged solely in tobacco might have made their "social irresponsibility" more apparent, and made it easier to isolate those companies through strategies such as divestment. ${ }^{7}$ Some of these advantages might have also accrued to a lesser extent had Philip Morris only split the tobacco and food businesses.

While even the most ardent tobacco control advocates rarely imagine Philip Morris voluntarily getting out of the tobacco business, company documents show that such an option was on the table. The spin-off plan was taken further than the sell-off, but even that proposal shows the power of tobacco control. Indeed, Philip Morris's spin-off plan was its own way of isolating the tobacco business from its food holdings in order to control the downsides that a strong tobacco control environment was exacerbating. The fact that these plans were abandoned in favour of an image makeover and name change does not detract from its significance. Rather, it provides evidence that even within the tobacco industry there was an emerging awareness that "business as usual" cannot continue indefinitely.

Leery of being tagged as prohibitionists, many public health advocates, practitioners, and policymakers have resisted articulating the goal of eliminating the industry. Some have suggested, implicitly or explicitly, that such a goal is inappropriate or impossible. ${ }^{72}$ Instead, they have focused their efforts on reducing youth access and youth directed marketing, and promoting smoke-free workplaces and public accommodations. These approaches, while well intentioned and effective, fall short of directly aiming for the smoke-free society envisioned almost 20 years ago by Surgeon General C Everett Koop. ${ }^{74}$

\section{What this paper adds}

Research in the tobacco documents has focused on industry strategies designed to thwart tobacco control efforts in the scientific, legal, legislative, and regulatory arenas. Little work has addressed the effects tobacco control efforts have had on the tobacco business. Philip Morris's proposed spin-off of their tobacco business in the early 1990s was reported in the business press, but its internal development has not been evaluated in the political context of tobacco control.

This study shows that Philip Morris management's proposal to jettison the tobacco business was prompted by the successful efforts of tobacco control activists to alter the company's business environment. Company documents suggest that efforts to denormalise the industry have figured prominently in the development of business strategies. Tobacco control activists have focused on minimising the harms of tobacco use by restricting marketing practices and promoting smoke-free public spaces, assuming that discussions of eliminating the industry were tantamount to calls for prohibition. This paper suggests that legal prohibition of tobacco is not a prerequisite for denormalising, and perhaps eventually ending, the industrial production of tobacco.

This study suggests that ongoing efforts aimed at denormalising the industry have the potential to destabilise, reduce or even eventually eliminate the industrial production of tobacco. A decade ago, in the absence of any threat to the legality of tobacco, the largest US tobacco company considered either spinning off or exiting the "dying" business, in large part because of the effectiveness of tobacco control efforts. Elimination of tobacco as a corporate enterprise, therefore, should be distinguished from legal prohibition of tobacco products. Rather, as this study shows, phasing out the industry may be possible through a combination of public pressure, media attention, regulation, taxation, and litigation that disrupts the industry's carefully crafted image and renders the business climate increasingly inhospitable. That Philip Morris continues to feel pressure from tobacco control initiatives such as the World Health Organization enquiry ${ }^{4}$ is evidenced by the company's intention to change its name. Other strategies, such as generic packaging requirements, that reduce the value of branding also may be powerful tools for tobacco control. Such sustained, industry focused efforts may help Philip Morris-and other companies-eventually kick the tobacco habit for good.

\section{ACKNOWLEDGEMENTS}

We thank Naphtali Offen, Nathaniel Wander, Derek Yach, and Richard Daynard for their comments, and Joshua Dunsby for research assistance.

Funding: National Cancer Institute, R01CA090789-01, California Tobacco-Related Disease Research Program, 11RT-0139

\section{Authors' affiliations}

E A Smith, *R E Malone, Department of Social \& Behavioral Sciences, School of Nursing, University of California, San Francisco, San Francisco, California, USA

*Also Center for Tobacco Control Research \& Education, University of California, San Francisco

\section{REFERENCES}

1 Yach D, Bettcher D. Globalisation of tobacco industry influence and new global responses. Tobacco Control 2000;9:206-16.

2 Malone RE. Tobacco industry surveillance of public health groups: the case of STAT and INFACT. Am J Public Health 2002;92:955-60. 
3 Carter SM. Mongoven, Biscoe \& Duchin: destroying tobacco control activism from the inside. Tobacco Control 2002;11:112-8.

4 Committee of Experts on Tobacco Industry Documents. Tobacco company strategies to undermine tobacco control activities at the World Health Organization. Geneva, Switzerland: World Health Organization, 2000.

5 Yach D, Bialous SA. Junking science to promote tobacco. Am J Public Health 2001;91:1745-8.

6 Cohen JE, Ashley M, Ferrence R, et al. Institutional addiction to tobacco. Tobacco Control 1999;8:70-4

7 Yach D, Brinchmann S, Bellet S. Healthy investments and investing in health. Journal of Business Ethics 2001:33:191-8.

8 Hicks JJ. The strategy behind Florida's "truth" campaign. Tobacco Control 2001;10:3-5.

9 Sly DF, Heald GR, Ray S. The Florida "truth" anti-tobacco media evaluation: design, first year results, and implications for planning future state media evaluations. Tobacco Control 2001;10:9-15.

10 Altria. Altria. URL: http://www.Altria.com/2003

11 Smith EA, Malone RE. Altria means tobacco: Philip Morris's identity crisis. Am J Public Health (in press).

12 Malone RE, Balbach ED. Tobacco industry documents: treasure trove or quagmire? Tobacco Control 2000:9:334-8

13 Philip Morris. The reputation of Philip Morris/Jacobs Suchard/KGF in Europe. Philip Morris. September 1992. Access date 1 April 2002. Bates No. 2501343918/3958. URL: http://legacy.library.ucsf.edu/tid/ nwq22e00

14 Wirthlin Group. National quorum survey topline results. Philip Morris July 1993. Access date: 31 January 2002. Bates No. $2031599461 / 9475$. URL: http://legacy.library.ucsf.edu/tid/jbv17e00

15 Richardson D. Issues and image results. Philip Morris. 18 April 1994 Access date 1 April 2002. Bates No. 2022890713/0715. URL: http://legacy.library.ucsf.edu/tid/uvc78e00

16 Philip Morris. Continuous cigarette tracking study - 900300900400 company awareness module. Philip Morris. April 1990. Access date 29 January 2002. Bates No. 2060055417/5463. URL: http:// legacy.library.ucsf.edu/tid/dyi52e00

17 Stern D. PM corporate imagery. Philip Morris. 23 Augutst 1990. Access date 29 January 2002. Bates No. 2060055383/5384. URL http://legacy.library.ucsf.edu/tid/bqe72e00

18 Stern D. PM corporate imagery. Philip Morris. 13 August 1990. Access date 29 January 2002. Bates No. 2060055385/5388. URL: http://legacy.library.ucsf.edu/tid/cqe72e00

19 Wirthlin Group. Philip Morris Companies a national opinion survey. Philip Morris. December 1992. Access date 1 February 2002. Bates No. 20254 15379/5399. URL: http://legacy.library.ucsf.edu/tid/ dmn $85 \mathrm{e} 00$

20 Philip Morris. Meeting notes corporate I.D. brainstorming with Jerry Welsh 910219. Philip Morris. 19 February 1991. Access date 16 January 2002. Bates No. 2025417753/7756. URL: http:// legacy.library.ucsf.edu/tid/yzx88e00

21 Philip Morris, [Notebook- GLS Plan]. Philip Morris. March 1990. Access date 13 May 2002. Bates No. 2048302297/2344. URL: http://legacy.library.ucsf.edu/tid/nos65e00

22 Philip Morris. Operation Rainbow objective: do something about the declining media climate. Philip Morris. 1990. Access date 13 May 2002. Bates No. 2048302054/2056. URL: http:// legacy.library.ucsf.edu/tid/lps65e00

23 Philip Morris, Wirthlin Group. Philip Morris companies a national opinion survey - topline results. Philip Morris. Janaury 1993. Access date 4 February 2002. Bates No. $2031599541 / 9584$. URL: http://legacy.library.ucsf.edu/tid/lav42e00

24 Philip Morris. Corporate communications taskforce. Philip Morris. August 1995. Access date 21 June 2002. Bates No. 2045996032/ 6062. URL: http://legacy.library.ucsf.edu/tid/zdq18d00

25 Anon. Proposal orginated with WSU students in medicine; investments in tobacco companies stopped: smoking is bad for health. PR Newswire 7 June 1991

26 Parker M, Williams T. Tobacco stocks in harsh light. Pensions \& Investments 1990; 28 May:35.

27 Philip Morris. The global marketing of Philip Morris (Holt/Hughes presentation) 951103 . Philip Morris. 3 November 1995. Access date 24 June 2002. Bates No. 2046997376/7397. URL: http:// legacy.library.ucsf.edu/tid/mlg45d00

28 Burson-Marsteller. Adding value through communications. Philip Morris. June 1993. Access date 19 June 2002. Bates No. 2023027617/7661. URL: http://legacy.library.ucsf.edu/tid/xet71fo0.

29 Philip Morris. Planning meeting notes Williamsburg 930429-930501. Philip Morris. 29 April 1993. Access date 5 June 2002. Bates No. 2024142961 /2986. URL: http://legacy.library.ucsf.edu/tid/bcn09e00

30 Philip Morris Corporate. Philip Morris. 2 February 1993. Access date 29 May 2002. Bates No. 2048300202/0205. URL: http://legacy.library.ucsf.edu/tid/aqs65e00

31 Murray RW. R. William Murray speech Sea Island - Thursday, 940421. Philip Morris. 21 April 1994. Access date 7 June 2002. Bates No. 2048296810/6821. URL: http://legacy.library.ucsf.edu/tid/bgs65e00

32 Philip Morris. Q and A. Philip Morris. 1989. Access date 28 January 2002. Bates No. 2023277376/7384. URL: http:// legacy.library.ucsf.edu/tid/btw36e00

33 Philip Morris. Project down under conference notes. Philip Morris. 24 June 1987. Access date 22 May 2002. Bates No. 2021502102/2134. URL: http://tobaccodocuments.org/bliley_pm/23693.html\#images

34 Murray WR. The background. Philip Morris. September 1990. Access date 8 February 2002. Bates No. 2023027920/7949. URL: http://legacy.library.ucsf.edu/tid/fno24e00
35 Dollisson J. Public affairs campaigning or reflections on the tobacco wars. Philip Morris. 15 October 1990. Access date 17 June 2002. Bates No. 2023027897/7916. URL: http://legacy.library.ucsf.edu/tid/ rth46e00

36 Goldberg M. Strategic alternatives 940423 Marc Goldberg. Philip Morris. 23 April 1994. Access date 10 June 2002. Bates No. 2048299627/9661. URL: http://legacy.library.ucsf.edu/tid/vvp92e00

37 Miles MA. Michael A Miles Board notes. Philip Morris. 25 May 1994. Access date 12 June 2002. Bates No. 2048134985/4986. URL http://legacy.library.ucsf.edu/tid/our82e00

38 Murray RW. [Murray notes re: Rainbow]. Philip Morris. January 1991. Access date 17 June 2002. Bates No. 2023027864. URL: http://legacy.library.ucsf.edu/tid/wth46e00

39 Murray RW. Directors comments at Williamsburg 930431. Philip Morris. 31 April 1993. Access date 19 June 2002. Bates No. 2023028192/8203. URL: http://legacy.library.ucsf.edu/tid/ksh46e00

40 Lehman Brothers. Project Ocean discussion exhibits. Philip Morris. 19 July 1994. Access date 25 February 2002. Bates No. 2031590064/0141. URL: http://legacy.library.ucsf.edu/tid/crd12a00

41 CS 1 st Boston. Materials prepared for discussion Philip Morris Companies, Inc. Philip Morris. 13 September 1994. Access date 22 January 2002. Bates No. 2031593041/3086. URL: http:// legacy.library.ucsf.edu/tid/pbv17e00

42 Pratt T. RJR target-stock rumors raise eyebrows. Mergers \& Acquisitions Report 1993:4

43 Lesly E, Zinn L. A big thanks-but-no-thanks to RJR Nabisco. Business Week 1993:31.

44 Miles MA. Michael Miles Sea Island remarks Friday morning, 940422. Philip Morris. 18 April 1994. Access date 25 March 2002. Bates No. 2048299608/9616. URL: http://legacy.library.ucsf.edu/tid/ers65e00

45 Schoolman J. Philip Morris, RJR may spin off tobacco. Chicago Sun-Times 1994;16 April 16:30

46 Tomkins R. Philip Morris keeps the markets guessing - food and tobacco group has made an about-turn over a spin-off. Financial Times 1994;2 June :28

47 Anon. Philip Morris stock plunges as tobacco spin-off goes on hold. Buffalo News 1994:26 May.

48 Asfar R. More speculation on Philip Morris spinoff. Chicago Sun-Times 1994;24 May:49.

49 Collins G. Philip Morris decides not to split its units. New York Times 1994:26 May 1.

50 Tomkins R. No split for Philip Morris. Financial Times 1994;27 May:25.

51 Philip Morris. Ferocious defense of the tobacco industry. Philip Morris. September 1993. Access date 25 March 2002. Bates No. 2022886999/7000. URL: http://legacy.library.ucsf.edu/tid/qrc78e00

52 Miles MA. Ferocious defense. Philip Morris. 7 March 1994. Access date 25 March 2002. Bates No. 2022843127/3128. URL: http://legacy.library.ucsf.edu/tid/apo44e00

53 Philip Morris. Tobacco strategy review. Philip Morris. 22 March 1994. Access date 26 March 2002. Bates No. 2022838619/8650. URL: http://legacy.library.ucsf.edu/tid/ptk53e00

54 Philip Morris. [Rainbow details]. Philip Morris, 1993. Access date 14 June 2002. Bates No. 2023960309/0310. URL: http:// legacy.library.ucsf.edu/tid/wum46e00

55 Philip Morris. Negotiated givebacks. Philip Morris. June 1993. Access date 14 June 2002. Bates No. 2023960311 . URL: http:// legacy.library.ucsf.edu/tid/xum46e00

56 Philip Morris. Project Rainbow II elements. Philip Morris. 21 March 1994. Access date 17 June 2002. Bates No. 2022838666/8667. URL: http://legacy.library.ucsf.edu/tid/lko44e00

57 Philip Morris. Marketing priorities. Philip Morris. July 1994. Access date 17 June 2002. Bates No. 2046984765/4780. URL: http:// www.pmdocs.com/

58 Philip Morris. Rainbow II. Philip Morris. 1993. Access date 18 June 2002. Bates No. $2021183127 / 3131$. URL: http://www.pmdocs.com/ getallimg.asp? if=avpidx\&DOCID=2021183127/3131

59 Pak JA, Sherman SP, Williams M. How Philip Morris diversified right Philip Morris. 23 October 1989. Access date 28 January 2002. Bates No. 2023277081/7086. URL: http://legacy.library.ucsf.edu/tid/ lat24e00

60 Kluger R. Ashes to ashes: America's hundred-year cigarette war, the public health, and the unabashed triumph of Philip Morris. New York: Knopf, 1996.

61 Philip Morris. Follow-up points - corporate affairs. Philip Morris. 11 January 1989. Access date 28 January 2002. Bates No. 2023277501/7502. URL: http://legacy.library.ucsf.edu/tid/idx36e00

62 Wirthlin Group. Building a strategic positioning with impact for the Philip Morris Companies. Philip Morris. March 1993. Access date 4 February 2002. Bates No. 2023465153/5222. URL: http://legacy.library.ucsf.edu/tid/kgv71f00

63 PM image study initial findings. Philip Morris. 1993. Access date 29 January 2002. Bates No. $2031599499 / 9501$. URL: http:// legacy.library.ucsf.edu/tid/xwq77e00

64 KRC Research. [Believability of youth smoking statements]. Philip Morris. 10 November 1998. Access date 1 May 2002. Bates No. 2072908768. URL: http://legacy.library.ucsf.edu/tid/wrt27d00

65 Philip Morris USA. Philip Morris U.S.A. announces initiative against youth smoking. Philip Morris. 27 June 1995. Access date 30 January 2002. Bates No. 2501078456/8458. URL: http:// legacy. library.ucsf.edu/tid/ack49e00

66 Philip Morris. Philip Morris fights negative image activists claim efforts inadequate. Philip Morris. 28 June 1995. Access date 29 January 2002. Bates No. 204477965 1/9652. URL: http://legacy.library.ucsf.edu/tid/ qbf36e00 
67 Holm Group. [PM messages - survey results]. Philip Morris. July 1997. Access date 9 April 2002. Bates No. 2071004895/4906. URL: http://legacy.library.ucsf.edu/tid/zxm08d00

68 Carraro T. FW: Interview report. Philip Morris. 12 October 1999. Access date 9 July 2002. Bates No. 2072412017/2018. URL: http://legacy.library.ucsf.edu/tid/bsx28d00

69 Philip Morris. Draft PM21 internal boilerplate speech working to make a difference. The people of Philip Morris. Philip Morris. 14 July 1999. Access date 30 April 2002. Bates No. 2072141008/1021. URL: http://legacy.library.ucsf.edu/tid/ebf08d00
70 PM21 internal toolkit. Philip Morris. 4 August 1999. Access date 29 April 2002. Bates No. 2072446701/6739. URL: http:// legacy. library.ucsf.edu/tid/rlq27d00

71 Schwartz J. Philip Morris to change name to Altria. New York Times 2001;16 November: 1.

72 Bates C. What is the future for the tobacco industry? Tobacco Control 2000;9:237-8

73 Warner KE. What's a cigarette company to do? Am J Public Health 2002:92:897-900.

74 Koop CE. Call for a smoke-free society. Pediatr Pulmonol 1985;1:4-5.

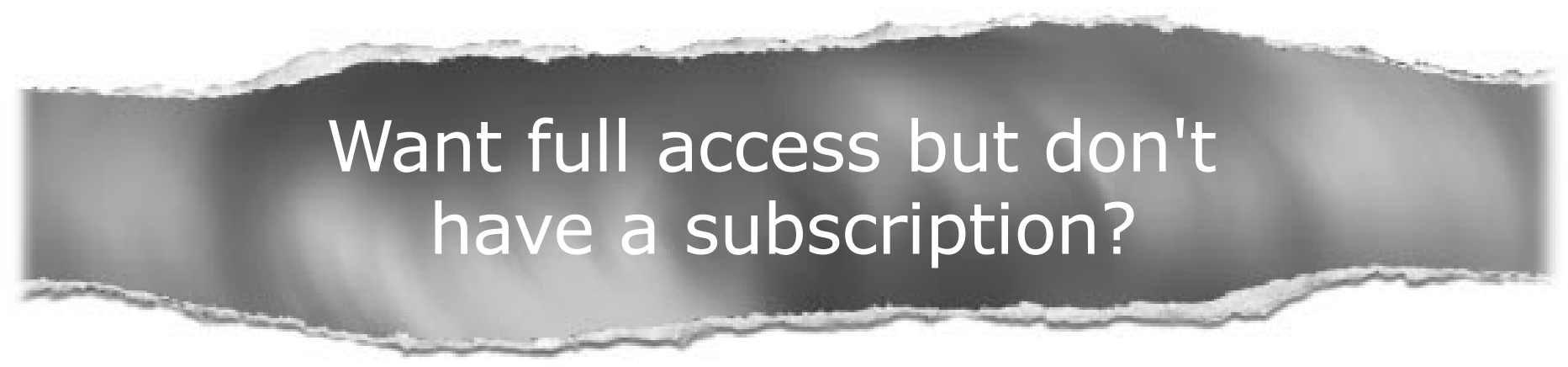

\section{Pay per access}

For just US $\$ 25$ you can have instant access to the whole website for 30 days. During this time you will be able to access the full text for all issues (including supplements) available. You will also be able to download and print any relevant pdf files for personal use, and take advantage of all the special features Tobacco Control online has to offer.

\section{www.tobaccocontrol.com}

